Historic, Archive Document

Do not assume content reflects current scientific knowledge, policies, or practices. 


\section{SPRING SURPLUS LIST \\ of the}

\section{FRASER NURSERY COMPANY \\ INCORPORATED \\ BIRMINGHAM, ALA.}

\section{For Nurserymen and \\ Dealers Only}

Prices in this list includes Balling and Burlapping where necessary. The cost of boxes to be added as follows:

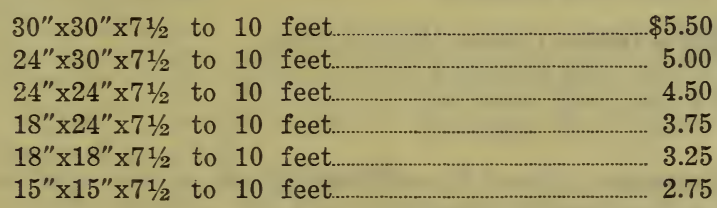

Terms Cash, but to parties of known responsibility or where satisfactory references are furnished we will extend usual terms.

Rates apply as follows: When 10 trees and not over 50 are ordered, the price will be $2 \frac{1 / 2}{\mathrm{c}}$ per tree more than the price per 100 . Orders for 50 trees or more up to 300 , when not less than 10 trees of each variety, will be charged for at the price per 100. Orders for 300 trees or more, when not less than 10 trees of each variety, will be charged for at the price per thousand.

Claims for damage or deficiencies must be made on receipt of goods.

Guarantee: We are very careful to keep each variety true to name as labeled, and are ready at any time to replace, on proper proof, any that may prove otherwise, free of charge, or refund the amount paid, but it is mutually agreed between the purchaser and ourselves that we shall at no time be liable for an amount larger than the original purchase price. 
NOTICE-All of the stock offered in this list is fresh dug at time of shipment-nothing stored-which insures fresh, vigorous plants. Shipments can be made on short notice unless digging is held up by inclement weather. Wire orders at our expense.

\section{DECIDUOUS SHRUBS}

\section{ALTHEA}

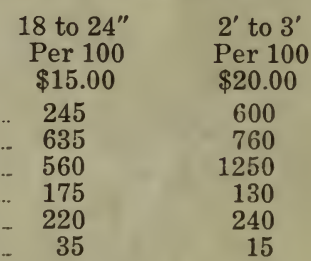

$3^{\prime}$ to $4^{\prime}$

Per 100

$\$ 25.00$

Anemonoeflora

Boule de Feu

Comte de Hainault

Duchess de Brabant

Lady Stanley

Totus Albus

35

25

185

BERBERIS Atropurpurea (Purple Barberry)

Per 100

175-2 to 3 feet, well branched

25.00

$350-3$ to 4 feet, well branched

35.00

CALYCANTHUS Florida (Sweet Shrub)

$30-2$ to 3 feet, well branched.

$40-3$ to 4 feet, well branched

DEUTZIA Pride of Rochester

2000-1 year for lining out

$200-18$ to 24 inches, branched

$150-2$ to 3 feet, well branched

$250-3$ to 4 feet, well branched

$150-4$ to 5 feet, well branched

$200-5$ to 6 feet, well branched

3.50

10.00

15.00

20.00

30.00

40.00

HYDRANGEA Quercifolia (Oak Leaved Hydrangea)

$150-3$ to 4 feet, well branched

60.00

LAGERSTROEMIA Indica (Crepe Myrtle) Pink

$200-3$ to 4 feet, well branched

150 - 4 to 5 feet, well branched

$100-5$ to 6 feet, well branched

40.00

50.00

65.00

LIGUSTRUM Amurense (Amoor River North Privet)

$75-3$ to 4 feet, heavily branched

17.50

$250-4$ to 5 feet, heavily branched

30.00

$100-5$ to 6 feet, heavily branched

40.00

LIGUSTRUM Ibota (Ibota Privet)

$300-5$ to 6 feet, heavily branched

35.00

LIGUSTRUM Regelianum (Regel's Privet)

$250-3$ to 4 feet, heavily branched

30.00

SPIREA Van Houttei

$5000-1$ year for lining out

Per M.

25.00

\section{WEIGELA Rosea}

500-1 year for lining out

$250-18$ to 24 inches, branched

$200-2$ to 3 feet, well branched

$150-3$ to 4 feet, extra heavily branched

30.00

Per M.

25.00

WEIGELA Hendersonia

$150-3$ to 4 feet, extra heavily branched 


\section{VINES AND PERENNIALS}

1000-Canna Eureka, 3 to 5 eyes

1000 -Canna Gustav Gumpert, 3 to 5 eyes

Per 100

7.50

Per M

7.50

65.00

2500-Canna King Humbert, 3 to 5 eyes

250-Canna Yellow King Humbert, 3 to 5 eyes

6.00

7.50

1500 -Coreopsis Lanceolata

2500-Gladiolus Mixed, Best Varieties

8.00

2.50

5000 - Tube Rose, Mexican

3.50

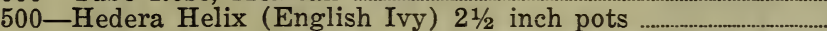

50 -Hedera Helix (English Ivy) 2 year field grown $\mathrm{xx}$ heavy

40 -Lonicera Belgica, 2 year No. 1 xx heavy

$40-2$ year No. 1 xx heavy

125-Miscanthus Sinensis Gracillimus (Pampas Grass) 3 year, heavy clumps

75-Miscanthus Sinensis Zebrinus (Striped Pampas Grass) 3 year, heavy clumps

15.00

30.00

30.00

30.00

90.00

90.00

35.00

150-Yucca Filamentosa, 3 year xx heavy

75 -Yucca Gloriosa, 3 year xx heavy

65.00

50.00

65.00

25.00

\section{SHADE TREES}

ACER Platanoides (Norway Maple)

$40-1 \frac{1}{2}$ to $1 \frac{3 / 4}{4}$ inches caliper, well branched

$60-13 / 4$ to 2 inches caliper, well branched

$100-2$ to $2 \frac{1}{2}$ inches caliper, heavily branched

$130-21 / 2$ to 3 inches caliper, heavily branched

$250-3$ to 4 inches caliper, heavily branched

40.00

ACER Saccharum (Sugar Maple)

$20-8$ to 10 feet, well branched

$25-1 \frac{1}{4}$ to $1 \frac{1 / 2}{2}$ inches caliper, well branched

$25-11 / 2$ to $13 / 4$ inches caliper, well branched

$30-13 / 4$ to 2 inches caliper, heavily branched

$25-2$ to $2 \frac{1}{2}$ inches caliper, heavily branched

Per 10 Per 100

12.50

100.00

17.50

150.00

$22.50 \quad 200.00$

$30.00 \quad 275.00$

$40.00 \quad 375.00$

10.00

75.00

12.50

15.00

20.00

22.50

100.00

125.00

175.00

200.00

CELTIS Occidentalis (Hackberry)

$125-8$ to 10 feet, branched

$200-11 / 2$ to 2 inches caliper, well branched

10.00

75.00

15.00

$200-2$ to $2 \frac{1}{2}$ inches caliper, well branched

125.00

200.00

CORNUS Florida (White Flowering Dogwood)

$120-6$ to 8 feet, well branched

$150-11 / 2$ to 2 inches caliper, well branched

$130-2$ to $2 \frac{1}{2}$ inches caliper, well branched

65.00

9.00

12.50

100.00

17.50

150.00

GINKGO Biloba

$45-4$ to 5 feet, branched and whips

8.50

60.00

$40-5$ to 6 feet, branched

10.00

75.00

LIQUIDAMBAR Styraciflua (Sweet Gum) transplanted

$150-1 \frac{1}{2}$ to 2 inches caliper, well branched

17.50

150.00

MELIA Azedarach (Texas Umbrella)

$35-4$ to 6 feet, well branched

$120-6$ to 8 feet, well branched

$25-8$ to 10 feet, heavily branched

7.50

50.00

10.00

75.00

$17.50 \quad 150.00$

PLATANUS Occidentalis (American Sycamore)

$235-6$ to 8 feet, branched

$215-8$ to 10 feet, branched

7.50

9.00

50.00

65.00

$80-1 \frac{1}{2}$ to $1 \frac{3}{4}$ inches caliper, well branched

125.00

$75-13 / 4$ to 2 inches caliper, well branched

15.00

150.00

$110-2$ to $2 \frac{1}{2}$ inches caliper, heavily branched

20.00

175.00

$65-2 \frac{1}{2}$ to 3 inches caliper, heavily branched

200.00

PLATANUS Orientalis (Oriental Plane)

$200-6$ to 8 feet, branched

$100-8$ to 10 feet, branched 


\section{SHADE TREES-(Continued) \\ PLATANUS Orientalis (Oriental Plane)-(Continued)}

$100-1 \frac{1 / 2}{2}$ to $1 \frac{3 / 4}{4}$ inches caliper, branched

$75-13 / 4$ to 2 inches caliper, well branched

$50-2$ to $2 \frac{1}{2}$ inches caliper, well branched

$10-2 \frac{1}{2}$ to 3 inches caliper

Per 10

15.00

17.50

20.00

22.50

1.25

2.25

3.25

4.25

9.00

11.50

65-12 to 15 feet, well branched

$60-15$ to 18 feet, well branched

POPULUS Deltoides Monilifera (Carolina Poplar)

$60-6$ to 8 feet, branched

$70-8$ to 10 feet, branched

$110-10$ to 12 feet, well branched

$100-12$ to 15 feet, well branched

$35-15$ to 18 feet, well branched

2.25

2.75

3.75

5.25

9.00

12.50

15.00

17.50

$20-8$ to 10 feet, well branched
$15-10$ to 12 feet, well branched

CUS Palustris (Pin Oak)

$20-6$ to 8 feet, branched

ULMUS Americana (American Elm)

$1000-6$ to 8 feet, branched

$1000-8$ to 10 feet, branched

$750-1 \frac{1}{4}$ to $1 \frac{1}{2}$ inches caliper, well branched

$500-1 \frac{1}{2}$ to $1 \frac{3 / 4}{4}$ inches caliper, well branched

$450-13 / 4$ to 2 inches caliper, well branched

$900-2$ to $2 \frac{1}{2}$ inches caliper, well branched

$50-21 / 2$ to 3 inches caliper, well branched

$75-3$ to 4 inches caliper, well branched

2.75

4.25

9.00

11.50

13.50

17.50

25.00

37.50

12.50

15.00

20.00

22.50

$20-13 / 4$ to 2 inches caliper, well branched
$60-2$ to $21 / 2$ inches caliper, well branched

\section{BROAD LEAVED EVERGREENS}

BOXWOOD

Prices Include B \& B Where Necessary.

Per 10

42.50

32.50

42.50

25 Pyramids-24 to 30 inches high

2.75

12.50

17.50

$30-2$ to 3 feet, extra heavy
$100-3$ to 4 feet, extra heavy

us)

7.50

8.50

10.00

$90-15$ to 18 inches, branch
$60-18$ to 24 inches, bushy

2.75

10.00

12.50

$15-2$ to 3 feet, extra heavy

$30-3$ to 4 feet, extra heavy

EUONYMUS Radicans Variegata (Variegated Climbing Bittersweet) $350-12$ to 18 inches, light

$25-18$ to 24 inches

$30-30$ to 36 inches, extra heavy
25.00

100.00

150.00

50.00

60.00

75.00

25.00

75.00

100.00

125.00

175.00

10.00

30.00

65.00

90.00

20.00

35.00

50.00

100.00

125.00

25.00

65.00

90.00

150.00

25.00

100.00

225.00

100.00
125.00 


\section{BROAD LEAVED EVERGREENS-(Continued)}

EUONYMUS Sieboldi (Siebold's Burning Bush)

Per 10

4.25

10.00

12.50

$250-2$ to 3 feet, extra heavy

$300-3$ to 4 feet, extra heavy

GARDENIA Jasminoides (Cape Jasmine)

50-12 to 18 inches, branched

4.25

10.00

12.50

17.50

27.50

$50-4$ to 5 feet, well branched

$25-5$ to 6 feet, well branched

LAUROCERASUS (English Laurel)

$25-5$ to 6 feet, extra well formed specimens

62.50

17.50

22.50

-5 to 6 feet, heavy specimens

$150-6$ to 7 feet, heavy specimens
Per 100

40.00

75.00

100.00

40.00

75.00

100.00

150.00

250.00

600.00

150.00

200.00

110.00

175.00

225.00

20.00

25.00

15.00

17.50

22.50

125.00

150.00

200.00

150.00

250.00

300.00

350.00

450.00

37.50

47.50

15.00

17.50

22.50

27.50

37.50

125.00

150.00

200.00

250.00

350.00

15.00

20.00

$35-4$ to 5 feet, well branched

(20.00

10.00

12.50

15.00

$22.5 \mathrm{C}$

30.00
75.08

100.06

125.00

200.00

275.00

\section{CONIFEROUS EVERGREENS}

Prices include $\mathrm{B} \& \mathrm{\&}$, where necessary. These plants were produced for high class retail and landscape trade. They have been frequently transplanted and given sufficient room for proper development. No expense has been spared to produce trees of highest quality, and we do not believe there are any finer trees on the market today.

BIOTA Aured Conspicua (Erect Golden Arborvitae)

$80-30$ to 36 inches, nicely formed

50 - 3 to 4 feet, nicely formed

$30-4$ to 5 feet, specimens 


\section{CONIFEROUS EVERGREENS-Continued)}

BIOTA Aurea Nana (Dwarf Golden Arborvitae)

Per 10

Per 100

$75-18$ to 24 inches, nicely formed

17.50

$20-24$ to 30 inches, specimens

25.00

BIOTA Orientalis (Chinese Arborvitae)

100-6 to 8 feet, specimens

37.50

$125-8$ to 10 feet, specimens

CEDRUS Deodara (Deodar Cedar)

$25-30$ to 36 inches, well formed

22.50

$30-3$ to 4 feet, well formed

30.00

$25-5$ to 6 feet, specimens

50 -6 to 8 feet, heavy specimens

60.00

85.00

CUPRESSUS Royali

$10-2$ to 3 feet

15.00

$15-3$ to 4 feet

20.00

$10-4$ to 5 feet

30.00

JUNIPERUS Communis (English Juniper)

10-6 to 7 feet, heavy specimens

50-7 to 9 feet, heavy specimens

75.00

100.00

JUNIPERUS Sinensis Argentea Variegata (Variegated Chinese Juniper)

$20-4$ to 5 feet, heavy specimens

65.00

$15-5$ to 6 feet, heavy specimens

100.00

JUNIPERUS Virginiana (Red Cedar, Eastern Type)

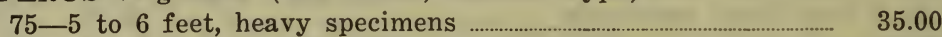

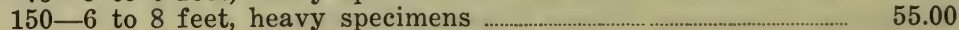

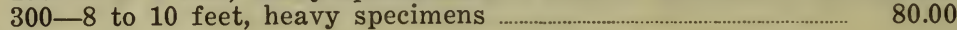

500.00

750.00

JUNIPERUS Virginiana Pendula (Weeping Red Cedar)

$10-4$ to 5 feet, specimens

35.00

$15-6$ to 7 feet, specimens

$20-7$ to 8 feet, specimens

50.00

75.00

JUNIPERUS Tripartita

15-3 to 4 feet, specimens

$20-4$ to 5 feet, specimens

$15-5$ to 6 feet, specimens

35.00

50.00

75.00

RETINOSPORA Filifera '(Thread Branched Japanese Cypress)

$50-24$ to 30 inches, nicely formed

$20-30$ to 36 inches, nicely formed

$10-4$ to 5 feet, specimens

$10-5$ to 6 feet, specimens

25-6 to 7 feet, heavy specimens

$20-10$ to 12 feet, heavy specimens

20.00

30.00

50.00

65.00

85.00

125.00

RETINOSPORA Pisifera Aurea (Pea Fruited Golden Japanese Cypress)

$40-3$ to 4 feet, specimens

$35-4$ to 5 feet, specimens

35.00

25-5 to 6 feet, heavy specimens …………………….................... 50.00

$30-6$ to 7 feet, heavy specimens ..................................................... 75.00

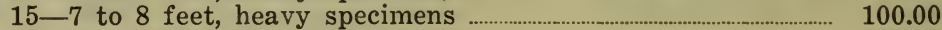

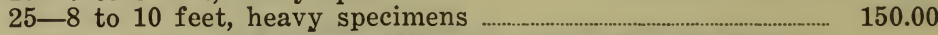

RETINOSPORA Plumosa Argentea (Dwarf Silver Tipped Cypress)

$75-12$ to 18 inches, nicely branched

12.50

RETINOSPORA Plumosa Aurea (Golden Plume Cypress)

$50-4$ to 5 feet, specimens

35.00

$30-5$ to 6 feet, heavy specimens

50.00

$35-6$ to 7 feet, heavy specimens

75.00

$20-7$ to 8 feet, heavy specimens

100.00

$25-8$ to 10 feet, heavy specimens

150.00

$10-10$ to 12 feet, heavy specimens

200.00 


\section{CONIFEROUS EVERGREENS-(Continued)}

RETINOSPORA Plumosa (Plume Cypress)

Per 10

35.00

50.00

75.00

100.00

150.00

200.00

10.00

15.00

20.00

-2 to 3 feet, nicely formed

$40-3$ to 4 feet, nicely formed

10.00

15.00

20.00

$20-18$ to 24 inches, nicely formed

$15-30$ to 36 inches, nicely. formed

\section{ROSES}

Own Roots, Two Years Old, No. 1 Grade

Per 100

$\$ 45.00$

50-Alexander Hill Gray, T. Yellow

80 - Baby Rambler, P. Bright Crimson

45.00

40-Bessie Brown, H. T. Creamy White

40-Climbing Gruss an Teplitz, C. C. Dazzling Crimson

70 -Dr. W. Van Fleet, W. Flesh Pink

120-Double Laevigata, L. Pure White

45.00

35.00

35.00

10-Ellen Poulson, P. Dark Brilliant Pink

50-Etoile de France, H. T. Crimson-red

70 - Gruss an Teplitz, C. Bright Crimson

45.00

45.00

45.00

40-Helen Gould, H. T. Watermelon Red

150 - Jessie, P. Cherry Crimson

280 -Jonkheer J. L. Mock, H. T., Imperial Pink

45.00

45.00

45.00

45.00

50 -K. A. Victoria, H. T. Pure white

60-Killarney, H. T. Pink

20-Killarney Brilliant, H. T. Brilliant Pink

190-Mrs. W. H. Cutbush, P. Delicate Pink

60-Mrs. Chas. Russell, H. T. Rosy Pink

40 -Orleans, P. Deep Cerise

40-Perle des Jardinns, T. Deep Straw-yellow

150-Pink Cochet T. Light Pink

260-Radiance, H. T. Brilliant Rosy Carmine

200-Red Radiance, H. T. Crimson-scarlet

200-Rhea Reid, H. T. Dark Velvety Red

150-White Cochet, T. Creamy White

40-Melody-T. Clear Yellow

200-My Maryland-H. T. Clear Intense Pink

20-Richmond-H. T. Rich Scarlet

These Roses are fresh dug at time of shipment-nothing handled from storage. On account of mild weather prevailing during February growth has started slightly, and we cannot accept orders except for immediate shipment. Wire orders may be sent collect. 
